\title{
Specifics of the chemical composition of atmospheric precipitation in the Southern Baikal region
}

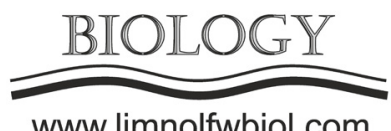

www.limnolfwbiol.com

\author{
Netsvetaeva O.G.*, Golobokova L.P., Obolkin V.A., Nosova V.V., Lopatina I.N., \\ Khodzher T.V.
}

Limnological Institute, Siberian Branch of the Russian Academy of Sciences, Ulan-Batorskaya Str., 3 Irkutsk, 664033, Russia

\begin{abstract}
This work presents the results of the study of the ionic concentration and acidity of atmospheric precipitation in the city of Irkutsk and the Listvyanka settlement (the Southern Baikal region, Russia) from 2014 to 2019. Comparison of their chemical composition indicated that the precipitation in Listvyanka is less mineralized and more acidified. The frequency of acid precipitation $(\mathrm{pH}<5)$ in Listvyanka is two times higher than in Irkutsk. The concentrations of most ions (except for nitrates) on the Baikal coast are two-three times lower than in the industrial centre. From 2014 to 2019 , the precipitation of the Southern Baikal region shows the trend towards a decrease in the total ionic concentrations and $\mathrm{pH}$ value.
\end{abstract}

Keywords: Southern Baikal region, Irkutsk, Listvyanka, atmospheric precipitation, ionic concentrations, pH

Atmospheric precipitation is one of the most important factors, which determines the ecological situation in the natural environment. Therefore, it is important to monitor its chemical composition and detect trends in its change.

This study discusses the chemical composition of atmospheric precipitation in two settlements of the Southern Baikal region with different anthropogenic pressure: the industrial centre, the city of Irkutsk (population 624 thou people), and the Listvyanka settlement (approximately 2 thou people). The sampling was carried out in a regime of continuous monitoring. From 2014 to 2019, approximately 900 samples were taken and analysed for the concentration of major ions and $\mathrm{pH}$. Analyses were carried out in the accredited Laboratory of Hydrochemistry and Atmosphere Chemistry at Limnological Institute SB RAS using techniques recommended in the monitoring networks of international programmes (http://www.lin.irk.ru/).

The main sources of air pollution in Irkutsk are as follows: the Novo-Irkutskaya thermal power station (TPS), an aircraft plant, enterprises the construction and wood-processing industries, small heating plants and houses with stove heating, road and rail transport, and airport. In Listvyanka located in the southwest coast of Lake Baikal $70 \mathrm{~km}$ from Irkutsk, the main sources of air pollution are a heating plant, household stoves, road and water transport. Moreover, with the northwesterly winds prevailing in the region, the emissions from the industrial complexes of the Baikal region can reach the water area of Southern Baikal, affecting the precipitation.

In Irkutsk, during the study period, the total ionic concentration $\left(\Sigma_{\text {ions }}\right)$ in the precipitation varied from 0.7 to $266 \mathrm{mg} / \mathrm{dm}^{3}$. The long-term average value was $17.1 \pm 2.5 \mathrm{mg} / \mathrm{dm}^{3}$. Most often, the precipitation in Irkutsk was with $\Sigma_{\text {ions }} 1-10 \mathrm{mg} / \mathrm{dm}^{3}(47 \%)$ and 10 $20 \mathrm{mg} / \mathrm{dm}^{3}$ (28\%). The frequency of precipitation with $\Sigma_{\text {ions }}$ higher than $50 \mathrm{mg} / \mathrm{dm}^{3}$ was $5 \%$. In Listvyanka, $\Sigma_{\text {ions }}$ varied from 0.4 to $63 \mathrm{mg} / \mathrm{dm}^{3}$. The average annual value $\left(6.7 \pm 1.0 \mathrm{mg} / \mathrm{dm}^{3}\right)$ was 2.6 times lower than in Irkutsk. The precipitation with $\Sigma_{\text {ions }}$ of $0-5 \mathrm{mg} / \mathrm{dm}^{3}$ (43\%) and $5-10 \mathrm{mg} / \mathrm{dm}^{3}$ (41\%) was the most frequent. From 2014 to 2019, $\Sigma_{\text {ions }}$ decreased in the precipitation of Listvyanka and, more significantly, Irkutsk. The average concentrations of most ions in the precipitation of Irkutsk was two-three times higher than in Listvyanka. The exception is $\mathrm{NO}_{3}^{-}$, the concentrations of which were on average higher on the Baikal coast than in the industrial centre (Table 1). Most likely, this is due to the transport of nitrogen oxides from TPSs of Irkutsk and Angarsk with northwesterly winds as well as to an increase in the $\mathrm{NO}_{\mathrm{x}}$ concentrations resulted from the annual increase in the number of road and water transport in Listvyanka caused by the development of tourism (Obolkin et al., 2016, Netsvetaeva et al., 2018). The interannual dynamics shows an increase in the $\mathrm{NO}_{3}^{-}$and $\mathrm{K}^{+}$concentrations in the precipitation of Irkutsk and Listvyanka.

Major ions in the precipitation of Irkutsk and Listvyanka are $\mathrm{SO}_{4}{ }^{2-}(27-29 \%)$ and $\mathrm{Ca}^{2+}(19-22 \%)$. The average annual distribution of the ionic concentrations, 
Table 1. Average annual ionic concentrations in the atmospheric precipitation of the Southern Baikal region (from 2014 to 2019), $\mathrm{mg} / \mathrm{dm}^{3}$

\begin{tabular}{|c|c|c|c|c|c|c|c|c|c|}
\hline Station & $\mathrm{HCO}_{3}^{-}$ & $\mathrm{SO}_{4}{ }^{2-}$ & $\mathrm{NO}_{3}{ }^{-}$ & $\mathrm{Cl}^{-}$ & $\mathrm{Na}^{+}$ & $\mathbf{K}^{+}$ & $\mathbf{C a}^{2+}$ & $\mathbf{M g}^{2+}$ & $\mathbf{N H}_{4}{ }^{+}$ \\
\hline Irkutsk & $\frac{2.4-5.6}{3.51}$ & $\frac{4.7-7.3}{5.84}$ & $\frac{1.5-2.0}{1.73}$ & $\frac{0.9-1.8}{1.25}$ & $\frac{0.5-0.9}{0.67}$ & $\frac{0.3-0.6}{0.35}$ & $\frac{1.9-3.1}{2.70}$ & $\frac{0.2-0.4}{0.30}$ & $\frac{0.7-1.5}{0.92}$ \\
Listvyanka & $\frac{0.1-0.6}{0.31}$ & $\frac{2.3-3.4}{2.90}$ & $\frac{1.6-2.3}{1.93}$ & $\frac{0.2-0.3}{0.21}$ & $\frac{0.1-0.2}{0.15}$ & $\frac{0.2-0.3}{0.19}$ & $\frac{0.8-1.3}{0.92}$ & $\frac{0.1-0.2}{0.13}$ & $\frac{0.4-0.7}{0.44}$ \\
\hline
\end{tabular}

Note: numerator - minimum-maximum, denominator - average value.

as their relative contribution decreases, can be represented as follows:

For Irkutsk: $\mathrm{SO}_{4}{ }^{2-}>\mathrm{HCO}_{3}^{-}>\mathrm{NO}_{3}^{-}>\mathrm{Cl}^{-} ; \mathrm{Ca}^{2+}>$ $\mathrm{NH}_{4}^{+}>\mathrm{H}^{+}>\mathrm{Mg}^{2+}>\mathrm{Na}^{+}>\mathrm{K}^{+}$.

For Listvyanka: $\mathrm{SO}_{4}^{2-}>\mathrm{NO}_{3}^{-}>\mathrm{Cl}^{-}>\mathrm{HCO}_{3}^{-}$; $\mathrm{Ca}^{2+}>\mathrm{NH}_{4}^{+}>\mathrm{H}^{+}>\mathrm{Mg}^{2+}>\mathrm{Na}^{+}>\mathrm{K}^{+}$.

The seasonal differences in the ionic concentrations caused by the influence of natural and anthropogenic factors are specifics of the atmospheric precipitation in Listvyanka and Irkutsk. In snowfalls, the proportion of bicarbonates and calcium is significantly elevated in Irkutsk, as well as the proportion of nitrates and calcium in Listvyanka mainly due to an increase in the emissions from the regional heat power enterprises during the heating season (Table 2). In rainfalls, the contribution of sulphates, ammonium and hydrogen ions is significantly higher due to greater number of precipitation (from three to six times) and, consequently, better washing out of ash and dust particles containing $\mathrm{Ca}^{2+}$ and $\mathrm{HCO}_{3}^{-}$(Netsvetaeva et al., 2018).

The $\mathrm{pH}$ value in the Irkutsk precipitation varied from 4.04 to 9.21 , with the long-term average value of $5.87 \pm 0.88$. The $\mathrm{pH}$ values within the range of 6-6.5 were the most frequent (Fig. 1A). The amount of acid precipitation varied from $13 \%$ (2015) to $30 \%$ (2019). In Listvyanka, the average acidity for the study period was $5.10 \pm 0.52 \mathrm{pH}$ units, varying from 4.12 to 7.34. The precipitation with a $\mathrm{pH}$ of 4.5-5.0 and 5.0-5.5 was the most frequent. The frequency of the precipitation with $\mathrm{pH} \leq 4.5$ was three times higher than in Irkutsk (Fig. 1A). The amount of acid precipitation fluctuated in different years between 39 and 59\%, averaging 49\%. The interannual dynamics showed a trend towards a decrease in $\mathrm{pH}$ from 2014 to 2019 (Fig. 1B), which is due to a decrease in $\mathrm{HCO}_{3}{ }^{-}$and $\mathrm{Ca}^{2+}$ in precipitation as well as an increase in $\mathrm{NO}_{3}^{-}$.

\section{Conclusions}

Comparison of the chemical composition of

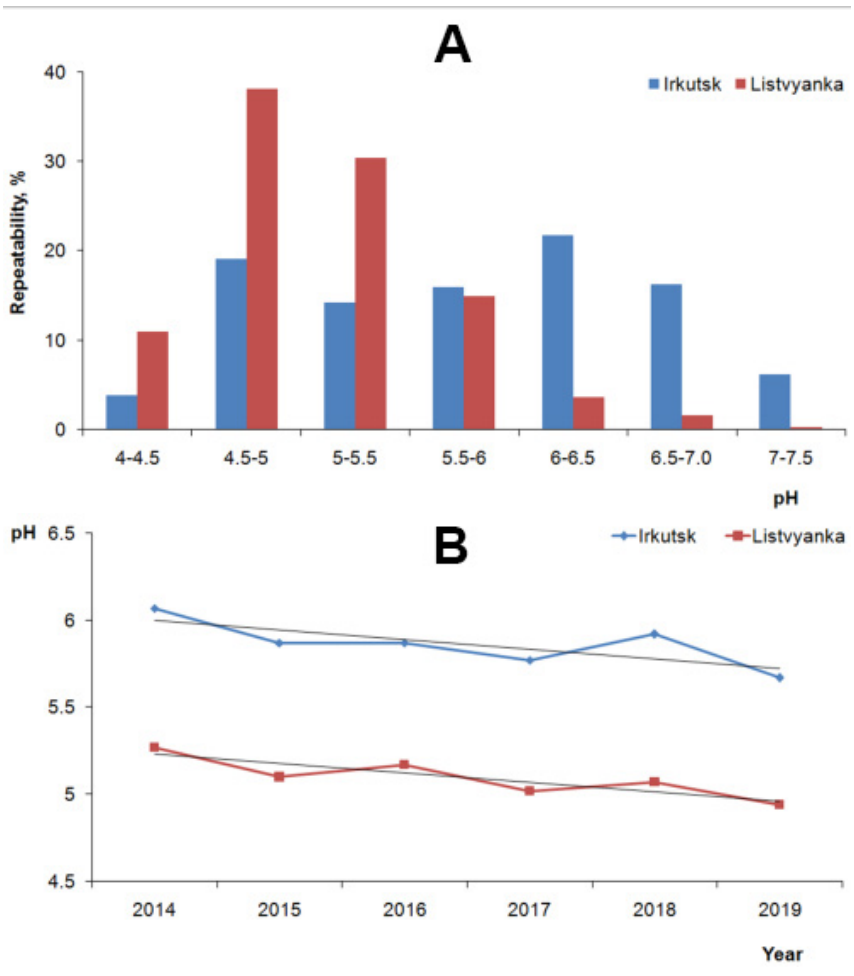

Fig.1. Frequency, \%, (A) and the interannual dynamics (B) of the $\mathrm{pH}$ value in atmospheric precipitation of the Southern Baikal region.

atmospheric precipitation in the areas of the Southern Baikal region with different anthropogenic pressure indicated higher atmospheric pollution in Irkutsk. In Listvyanka, the total ionic concentration was on average three times lower; the half of precipitation had pH values below 5. From 2014 to 2019, the atmospheric precipitation in the Southern Baikal region shows trends towards a decrease in the total ionic concentration and $\mathrm{pH}$ value.

The study was supported by the State Task 03452019-0008 and the RFBR grant No. 20-45-380024 r/a. Analytical works were carried out in Collective

Table 2. Relative ionic concentrations in atmospheric precipitation of the Southern Baikal region (from 2014 to 2019 ), $\%$

\begin{tabular}{|c|c|c|c|c|c|c|c|c|c|c|c|}
\hline Station & $\begin{array}{c}\text { Type of } \\
\text { precipitation }\end{array}$ & $\mathbf{H C O}_{3}^{-}$ & $\mathbf{S O}_{4}{ }^{2-}$ & $\mathbf{N O}_{3}^{-}$ & $\mathbf{C l}^{-}$ & $\mathbf{N a}^{+}$ & $\mathbf{K}^{+}$ & $\mathbf{C a}^{2+}$ & $\mathbf{M g}^{2+}$ & $\mathbf{N H}_{4}^{+}$ & $\mathbf{H}^{+}$ \\
\hline \multirow{2}{*}{ Irkutsk } & snow & 14.0 & 21.9 & 6.7 & 6.8 & 6.1 & 1.7 & 27.6 & 4.7 & 9.6 & 0.2 \\
& rain & 3.6 & 30.9 & 8.3 & 4.4 & 2.4 & 2.0 & 17.4 & 4.6 & 17.2 & 8.6 \\
Listvyanka & snow & 2.7 & 24.9 & 18.7 & 3.1 & 3.7 & 2.3 & 25.8 & 5.6 & 8.1 & 3.5 \\
& rain & 1.3 & 31.3 & 10.9 & 3.2 & 2.3 & 2.1 & 14.8 & 3.7 & 14.3 & 15.0 \\
\hline
\end{tabular}


Instrumental Centre "Ultramicroanalysis" at Limnological Institute SB RAS.

\section{References}

Netsvetaeva O.G., Golobokova L.P., Obolkin V.A. et al. 2018. Multiyear research of atmospheric deposition: case study at the Listvyanka monitoring station (Southern Pribaikalye, Russia). In: XXIV International Symposium on Atmospheric and Ocean Optics: Atmospheric Physics. DOI: $10.1117 / 12.2503867$

Obolkin V., Khodzher T., Sorokovikova L. et al. 2016. Effect of long-range transport of sulphur and nitrogen oxides from large coal power plants on acidification of river waters in the Baikal region, East Siberia. International Journal of Environmental Studies 73(3): 452-461. DOI: 10.1080/00207233.2016.1165481 